\title{
A simple method for determination of plasma and urinary biotin
}

\author{
Rahul S. Sanghvi ${ }^{a}$, Rosemary M. Lemons ${ }^{a}$, Herman Baker ${ }^{b}$ and \\ Jess G. Thoene ${ }^{\mathrm{a}, *}$ \\ ${ }^{a}$ Department of Pediatrics, University of Michigan School of Medicine, Ann Arbor, MI 48109 (USA) and \\ ${ }^{b}$ College of Medicine and Dentistry of New Jersey, East Orange, NJ (USA)
}

(Received December 18th, 1981; revision April 19th, 1982)

\section{Summary}

Measurement of biotin in plasma and urine has been stimulated by recent descriptions of inborn errors of biotin metabolism and by newly recognized causes of biotin deficiency. Biotin determination in physiologic fluids to document these conditions has been hindered by lack of a widely useable assay. This paper presents a method which employs tritium-labelled biotin, avidin, and nitrocellulose filters to measure urinary and plasma biotin in a rapid and simple manner.

\section{Introduction}

Biotin is a water-soluble vitamin which participates in a variety of carboxylase reactions in intermediary metabolism [1]. It has acquired renewed interest recently following the description of inborn errors of metabolism in which either biotin holocarboxylase synthetase is deficient or there is a disorder of biotin absorption or transport $[2,3]$. Symptomatic biotin deficiency resulting from intravenous alimentation has also recently been described [4]. Currently available methods to measure biotin at physiological concentrations rely on a bioassay using microorganisms [5]. Previous workers have described the use of avidin in protein-binding assays for biotin; however, these have lacked the sensitivity necessary to measure physiologic concentrations of biotin due to the low specific activity of the available $\left[{ }^{14} \mathrm{C}\right]$ carboxybiotin [6], or have required special synthesis of $\left[{ }^{125} \mathrm{I}\right]$ biotin [7] or $\left[{ }^{3} \mathrm{H}\right]$ biotin [8]. In addition, they have relied upon either charcoal or bentonite precipitation to separate bound from free biotin. The assay described in this paper overcomes these difficulties by using avidin to bind commercially available $\left[{ }^{3} \mathrm{H}\right]$ bio-

* Correspondence to Jess G. Thoene MD, Assoc. Prof. of Pediatrics, Kresge II R6032, University of Michigan School of Medicine, Ann Arbor, MI 48109, USA. 
tin of high specific activity, and nitrocellulose filters to separate the bound from free biotin.

\section{Materials and methods}

Nitrocellulose filters $(25 \mathrm{~mm}, 0.45 \mu, \mathrm{BA} 85)$ were purchased from Schleicher and Schuell, Keene, NH, USA; $d$-biotin was purchased from Sigma Chemical Company, St. Louis, MO, USA, as was avidin $(13 \mathrm{U} / \mathrm{mg}$ protein). One unit of avidin binds $1 \mu \mathrm{g}$ of biotin, therefore $1 \mathrm{U}$ equals approximately $1 \mathrm{nmol}$ of avidin. Tritiated biotin ( $d-\left[8,9-{ }^{3} \mathrm{H}(\mathrm{N})\right], \mathrm{Sp}$ act $36.4 \mathrm{Ci} / \mathrm{mmol}, 98 \%$ pure) was purchased from New England Nuclear, Boston, MA, USA, as was Omnifluor and Aquasol.

\section{Assay procedure}

To a series of 1-ml centrifuge tubes are added (in this order): $200 \mu 1$ of plasma ultrafiltrate or urine (diluted $1: 5$ and $1: 10$ in $150 \mathrm{mmol} / 1 \mathrm{NaCl}$ ), $10 \mu 1$ of $\left[{ }^{3} \mathrm{H}\right]$ biotin in aqueous solution containing $0.4 \mathrm{pmol}$ biotin (approximately $10000 \mathrm{cpm}, \mathrm{CE} 30 \%$ ), and $30 \mu \mathrm{l}$ of a $4 \mathrm{nmol}$ aqueous solution of avidin. The concentration of the avidin solution is determined by titration [7] against the $\left[{ }^{3} \mathrm{H}\right]$ biotin via the filtration procedure described below. This concentration of avidin yields optimal sensitivity for measuring biotin in the amounts found in plasma. Altering the amount of avidin in the assay changes the position of the binding curve, but does not alter the slope [7]. $225 \mu \mathrm{l}$ of each mixture is then aspirated through a nitrocellulose filter supported on the bottom half of a Swinnex-25 disc filter holder (Millipore Corp., Bedford, MA, USA) connected to a side arm flask. Vacuum is controlled by a 3-way stopcock connected to a water aspirator. The filters are washed with $0.6 \mathrm{ml}$ of $0.01 \mathrm{~mol} / 1 \mathrm{Na}$ acetate buffer, $\mathrm{pH} 5.0$, dried for $30 \mathrm{~min}$ under an infra-red lamp, and then placed in liquid scintillation vials containing $2 \mathrm{ml}$ of Omnifluor. The radioactivity bound to the filters is determined in a liquid scintillation counter (Beckman LSC-100, Beckman Instruments, Palo Alto, CA, USA). Urinary creatinine is measured by Jaffe's method [9].

A series of known biotin standards prepared in $150 \mathrm{mmol} / 1 \mathrm{NaCl}, \mathrm{pH} 7.0$, containing (in $200 \mu \mathrm{l}$ ) $0,50,100,250,500,750$ and $1000 \mathrm{pg}$ of biotin is run in parallel with the plasma and urine unknowns. Biotin standards and plasma and urine samples are stored frozen until analysis. The amount of radioactivity recovered for each biotin standard is expressed as a percent of the radioactivity recovered from tubes prepared without unlabelled biotin to produce a standard curve. Urine samples are run in duplicate undiluted, and diluted 1 to 5 and 1 to 10 in $150 \mathrm{mmol} / 1$ $\mathrm{NaCl}$. Plasma ultrafiltrate is prepared by centrifuging $1.0 \mathrm{ml}$ plasma obtained from heparinized whole blood through Amicon CX-25 filters at $600 \times \mathrm{g}$ for $30 \mathrm{~min}$. The biotin content of the unknowns is calculated from those dilutions which fall in the linear portion of the curve (approximately 100 to $1000 \mathrm{pg} / \mathrm{sample}$ ).

Neutral and acidic aqueous solutions ( $\mathrm{pH} 5.0-7.0)$ of biotin are stable for several months [10]. The biotin content of frozen plasma is stable for up to 1 year [11]. 


\section{Results and discussion}

In competitive protein-binding assays, labelled ligand and unknown compete for a limited number of binding sites on the protein. The amount of radioactivity bound to the protein is thus inversely proportional to the amount of unknown present in the sample. Using this method, the binding curve produced for biotin standards in the range of 50 to $1000 \mathrm{pg}$ of biotin is shown in Fig. 1. This curve is a composite of three separate standard curves run on three successive days. Recovery of $\left[{ }^{3} \mathrm{H}\right]$ biotin was relatively insensitive to $\mathrm{pH}$ over the range of 5-8. Recovery of radioactivity bound to the nitrocellulose filters was dependent upon molarity, as shown in Fig. 2. $\mathrm{NaCl}, 150 \mathrm{mmol} / \mathrm{l}$, was chosen as the diluent in the assay to minimize any variation induced by the salt content present in the urine samples analyzed. Recovery of bound radioactivity was constant if samples were filtered between 5 and $60 \mathrm{~min}$ after mixing. No radioactivity above background was recovered when avidin was omitted from the incubation mixture.

The recovery of known amounts of $d$-biotin added to plasma and urine is shown in Table I. Biotin recovery from urine and from plasma ultra-filtrate was between $75 \%$ and $134 \%$. The recovery obtained when biotin was added to whole plasma was less $(60-64 \%)$, presumably because some of the biotin binds to plasma proteins which are removed by the ultra-filtration procedure [12].

A series of plasma samples was analyzed for biotin content both by this method, and by the bioassay method of Baker et al [5]. The results are shown in Fig. 3. There is a good agreement between the two methods with a correlation coefficient of 0.987 .
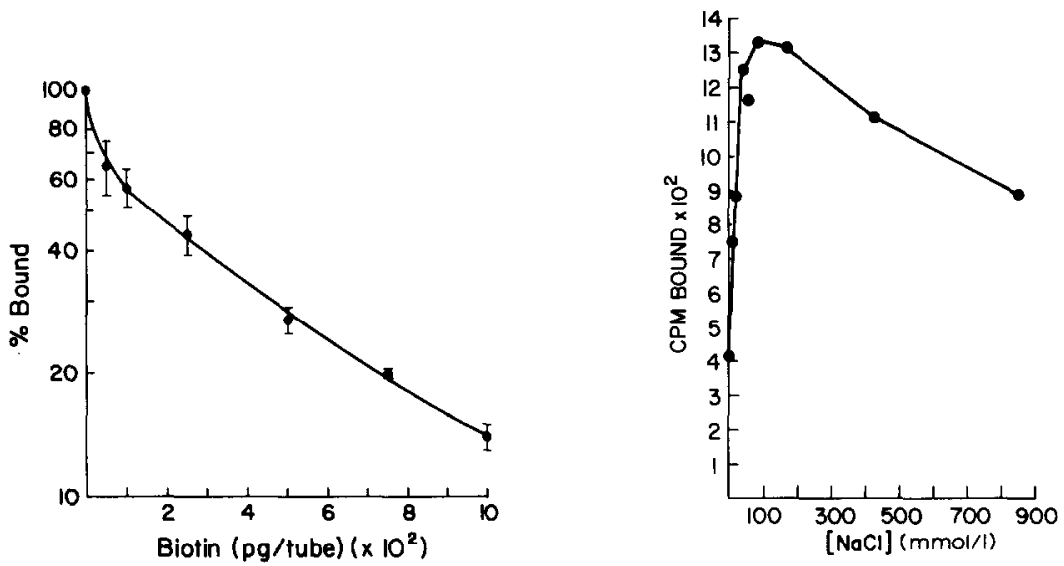

Fig. 1. Composite binding curve for the interaction of $\left[{ }^{3} \mathrm{H}\right]$ biotin and unlabelled biotin with avidin. The graph is derived from 3 separate curves run on 3 successive days. Points are the mean \pm 1 SD.

Fig. 2. The effect of molarity on the recovery of $\left[{ }^{3} \mathrm{H}\right]$ biotin bound to nitrocellulose filters. Tubes were prepared as described under Methods in solutions of varying concentrations of $\mathrm{NaCl}$ and lacking the addition of unlabelled biotin. The amount of radioactivity recovered was then plotted against the $\mathrm{NaCl}$ concentration. Points are the mean of duplicates. 
TABLE I

BIOTIN RECOVERY FROM PLASMA AND URINE

\begin{tabular}{|c|c|c|c|c|c|c|}
\hline \multirow{2}{*}{$\begin{array}{l}\text { Biotin added } \\
\text { (pg/tube) }\end{array}$} & \multirow[t]{2}{*}{ Plasma } & \multirow[t]{2}{*}{$\%$} & \multicolumn{4}{|c|}{ Biotin recovered } \\
\hline & & & $\begin{array}{l}\text { plasma } \\
\text { ultrafiltrate }\end{array}$ & $\%$ & urine & $\%$ \\
\hline 0 & 70 & & 105 & & 110 & \\
\hline 100 & 130 & 60 & 180 & 75 & 205 & 95 \\
\hline 250 & 230 & 64 & 375 & 108 & 445 & 134 \\
\hline 500 & 380 & 62 & 605 & 100 & 680 & 114 \\
\hline
\end{tabular}

Control plasma and urine samples were spiked with the indicated amounts of biotin and assayed in duplicate as described in 'Methods'. The recovery of biotin from whole plasma is lower than that obtained from plasma ultrafiltrate or urine, presumably because of binding to the plasma proteins with subsequent removal during ultrafiltration.

Within-run precision of this assay was based on 10 replicate assays performed on the same day on three dilutions of the same urine sample. The results were: low $340 \pm 50(\mathrm{SD}) \mathrm{pg} / \mathrm{ml}$ (CV 15\%); intermediate $815 \pm 120(\mathrm{SD}) \mathrm{pg} / \mathrm{ml}(\mathrm{CV} 15 \%)$; high $1930 \pm 250$ (SD) $\mathrm{pg} / \mathrm{ml}$ (CV 13\%). Long-term precision was determined by measuring the biotin content of a urine sample five times over a period of 21 days. This value was $14 \pm 3(\mathrm{SD}) \mathrm{ng} / \mathrm{ml}$, (CV 23\%).

Plasma and urinary biotin concentrations were determined by the avidin method and compared to published values obtained with the bioassay [3,4] (Table II). Random urine specimens were obtained from nine newborns in a neonatal intensive care unit and from 19 normal newborns in a full-term nursery. The normal newborns were younger than those in the special care unit and had a higher mean biotin excretion (118 ng/mg creatinine versus $84 \mathrm{ng} / \mathrm{mg}$ creatinine). Decline in

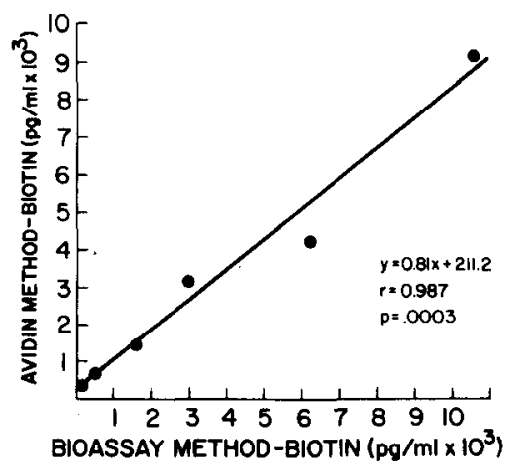

Fig. 3. The correlation between plasma biotin as measured by the avidin method, and the bioassay method. Six plasma samples were divided, kept frozen at $-20^{\circ} \mathrm{C}$, and assayed independently by each method. The correlation coefficient for the two methods is 0.987 ( $p=0.0003$ ). The standard error of the slope is 0.067 , and the standard error of the intercept is 346.3 . 
TABLE II

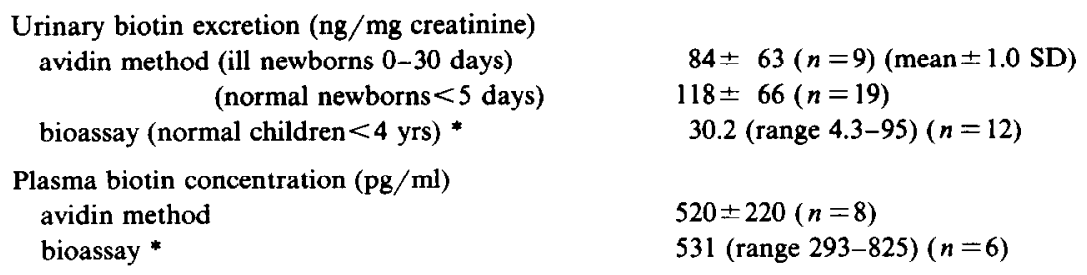

* From Ref. 3.

urinary biotin excretion from birth to a nadir at 4 weeks of age followed by a rise to adult values at about 6 months of age has been previously reported [13]. Plasma samples were obtained from eight healthy adult volunteers and assayed for biotin. The mean biotin concentration was $520 \mathrm{pg} / \mathrm{ml}$. This corresponded to the values obtained by the bioassay.

Avidin $\left(M_{\mathrm{r}} 66000\right)$ binds $4 \mathrm{~mol}$ of biotin per mol protein, and has been previously used in assays for biotin because of its availability and its high affinity for biotin $\left(K_{\mathrm{a}}=10^{15}\right)$. However, the previous methods have not employed nitrocellulose filters to separate bound from free biotin. Nitrocellulose filters bind protein non-specifically [14], and have been utilized to measure nanomolar amounts of cystine via a cystine-binding protein [15]. Application of this separation method combined with $\left[{ }^{3} \mathrm{H}\right]$ biotin of high specific activity provides a rapid and reliable procedure for the determination of plasma and urinary biotin. Utilization of this method should greatly enhance the ability to determine biotin deficiency states, and disorders of biotin absorption.

\section{Acknowledgements}

This research was supported in part by grants AM 25548 + 5MO1RR42 from the National Institutes of Health, and The Michigan Department of Mental Health. Presented at the Annual Meeting, Society for Pediatric Research, Washington, DC, May 11, 1982.

We thank Dr. Charles Sing for assistance with the statistical analyses, Dr. A. Rees Midgely for helpful critical comments, and Mrs. Phyllis Newberry for excellent secreterial assistance.

\section{References}

1 Wood HG. Biotin enzymes. In: Snell E, Royer P, Meister A, Richardson C, eds. Ann Rev Biochem 1977; 46: 385-413.

2 Saunders M, Sweetman L, Robinson B, Roth K, Cohn R, Gravel R. Biotin-responsive organic aciduria: multiple carboxylasc defects and complementation studics with propionic acidemia in cultured fibroblasts. J Clin Invest 1979; 64: 1695-1702. 
3 Thoene J, Baker H, Yoshino M, Sweetman L. Biotin responsive carboxylase deficiency associaled with subnormal plasma and urinary biotin. N Engl J Med 1981; 304: 817-820.

4 Mock D, deLorimer A, Liebman W, Sweetman L, Baker H. Biotin deficiency: an unusual complication of parenteral alimentation. N Fingl J Med 1981; 304: 820-823.

5 Baker H, Frank O, Matovitch VB, et al. A new assay method for biotin in blood, serum, urine, and tissues. Anal Biochem 1962; 3: 31-39.

6 Dakshinamurti K, Landman A, Ramamurti L, Constable R. Isotope dilution assay for biotin. Anal Biochem 1974; 61: 225-231.

7 Horsburgh T, Gompertz D. A protein-binding assay for measurement of biotin in physiological fluids. Clin Chim Acta 1978; 82: 215-223.

8 Dakshinamurti K, Allan L. Isotope dilution assay for biotin. Use of $\left[{ }^{3} \mathrm{H}\right]$ biotin. Methods Enzymol 1979; 62: 284-287.

9 Archibald R. Reactions of creatinine with alkaline picrate. J Biol Chem 1962; $237: 612$.

10 Windholz M. The Merck index. Merck and Co., Inc., 1976: 162.

11 Baker H. Unpublished observations.

12 Suchy S, Wolf B. Protein bound biotin: a consideration in multiple carboxylase deficiency. Lancet 1982; 1: 1108 .

13 Bonjour JP. Biotin in man's nutrition and therapy - a review. Intern J Vit Nutr Res 1977; 47: $107-118$.

14 Kuno H, Kihara H. Simple microassay of protein with membrane filter. Nature 1967; $215: 974-975$.

15 Oshima R, Willis R, Furlong C, Schneider J. Binding assays for amino acids: the utilization of a cystine binding protein from $E$. coli for the determination of acid-soluble cystine in small physiological samples. J Biol Chem 1974; 249: 6033-6039. 